\title{
Patterns of gene expression in microarrays and expressed sequence tags from normal and cataractous lenses
}

\author{
Konstantinos Sousounis and Panagiotis A Tsonis
}

\begin{abstract}
In this contribution, we have examined the patterns of gene expression in normal and cataractous lenses as presented in five different papers using microarrays and expressed sequence tags. The purpose was to evaluate unique and common patterns of gene expression during development, aging and cataracts.
\end{abstract}

Keywords: Lens, Microarray, Cataract, EST

\section{Introduction}

The lens is the organ inside the eye dividing it into two chambers: the aqueous humor in the anterior side and the vitreous humor in the posterior side. Lens focuses light from the environment to the retina for correct vision. The cornea is the most anterior surface that is in contact with the aqueous humor and the environment. Both the cornea and lens originated from the surface ectoderm during development. During gastrulation, the ectoderm is patterned to be the presumptive lens ectoderm and retina. Neurulation makes the presumptive retina tissues invaginate and become part of the neural ectoderm, which will form the optic vesicle, and it interacts with the presumptive lens ectoderm in later stages of neurula. In this stage, the fate of the presumptive lens ectoderm is already determined, and the induction of lens begins with the lens placode, which will evaginate to form the lens vesicle. The lens vesicle will give rise to mature lens, which is polarized with lens epithelium in the anterior side and differentiated lens fibers in the posterior (for reviews see [1-5]).

During all these steps, signaling pathways, transcription factors and gradients of growth factors play essential role in patterning the different tissues, making them competent in forming the appropriate tissues, stabilizing their fate during the development of the organism and finally differentiate them to play their designated role

\footnotetext{
* Correspondence: ptsonis1@udayton.edu

Department of Biology and Center for Tissue Regeneration and Engineering, University of Dayton, Dayton, $\mathrm{OH}$ 45469-2320, USA
}

[6,7]. Some of these factors are paired box protein 6 (Pax6) [8-35], sex determining region Y-box 1 (Sox1), Sox2, Sox3 [16,28,31,36-43], sine oculis homeobox homolog 3 (Six3) [17,32,44-46], pituitary homeobox 3 (Pitx3), [47-54], prospero homeobox protein 1 (Prox1), [23,55-60], transcriptional factor of the fork head family (Fox3e), [61-64], leucine zipper transcription factors of the maf family [65-70], fibroblast growth factors (FGF) [71-99], fibroblast growth factor receptors (FGFR) [91,94,100-105], bone morphogenetic proteins 4 (Bmp4), bone morphogenetic protein 7 (Bmp7) [106-109] Bmps/ TGFb and their receptors [110-117], extracellular matrix (fibrin, laminin and fibronectin) [118-121], integrin signaling [122-124], insulin [125,126], insulin-like growth factor-1 (IGF-1) [127] and activator protein 2 (AP2) $[128,129]$.

Functional analysis for most of these factors using transgenic animal models revealed that they associate with known diseases. Disruption of one or more of these factors from their normal role during development leads to abnormal phenotypes. In lens, most of the abnormal phenotypes result to cataract, a term which is used for all the situations where light cannot pass through the lens or it is scattered but not focused on the retina. Crystallins, the most abundant proteins in the lens, which also make the lens transparent, are disorganized during cataract. Cataract has many forms and causes, and it can change depending on the age and the region of the globe [130-135]. Classification depends on the patient's age, location in the lens, maturity stage and 
cause. Cataract can be formed together with other developmental disorders depending on mutations of factors that play roles in the differentiation of the lens, such as Pitx3 [136], crystallins, ferritin, connexins, aquaporins, LIM2, filensin, phakinin, heat shock transcription factor 4, Foxe3, Chx10, Maf family, Pax6, Gcnt2, Chmp4b (reviewed [137]), extracellular matrix (Capsule), fibrillin1 [138], lysyl oxidase-like 1 (Loxl1) [139-141], laminin subunit b2 (lam-b2) [142], collagen IV a1 (col4a1) [143], collagen IV a3 (col4a3), collagen IV a4 (col4a4), collagen IV a5 (col4a5) [144], collagen XVIII [145], fibronectin [146], Sparc $[147,148]$, collagen type I [149-151], FGF receptors [105], matrix metalloproteinases 2 and 9 $[152,153]$ and integrins [154]. Similarly, metabolic diseases like diabetes, which leads to accumulation of glucose products inside the lens, can result in cataracts $[155,156]$. Also, there are certain genetic syndromes that contribute to cataract formation, such as Nance-Horan syndrome $[157,158]$, Lowe syndrome (neurofibromatosis type 2) [136], hyerferritinemia cataract syndrome, Marfan syndrome [138], pseudoexfoliation syndrome [159], Pierson syndrome, Alport's syndrome [144,160], Knobloch syndrome [145] and phacotoxic uveitis [161,162]. However, despite the high percentage of success in cataract surgeries, complication can result in secondary cataract. The most important mechanism that is recognized to play a role in secondary cataract formation is the Epithelial-Mesenchymal Transition (EMT). This pathway is heavily studied because of its role in different kinds of situations, pathological or developmental $[151,163,164]$. TGFb is the soluble protein that activates this pathway in the lens epithelial cells to differentiate to fibro-myoblasts and not to lens fiber cells, which eventually leads again to opacification of the lens.

Age is a factor that influences many molecular, genetic and metabolic networks. For example, in lens, the lens capsule becomes thicker with age [165-167]. The lens loses functional properties and changes its protein contents. Membranes become harder, and that can influence the function of transmembrane proteins playing a role in cell-cell communication or homeostasis like aquaporins or connexins. The appearance of an internal lens barrier may play a role in preventing the smooth transportation of molecules in and out of this avascular tissue $[168,169]$. This might result in accumulation or lack of certain molecules, which can result in cataract. Furthermore, modifications in proteins appear in aged lens. These modifications can be cleavage of structurally important proteins like crystallins or modifications in certain residues, which can lead to altered interactions with other molecules. Finally, the lens' UV defenses are lost with age. UV can cause many structural alterations to proteins, resulting in lens opacification $[170,171]$. Oxidative stress is very important in cataract formation and is extensively studied [172]. Reduced levels of glutathione are the major cause of age-related nuclear cataract $[130,171,173,174]$. Additionally, proteins are oxidized, modified and cross-linked, so they lose their functional properties. Also, hyperoxide with metals can influence molecular and homeostatic regulation in the lens, resulting in age-related nuclear cataract (see review [171]).

As discussed above, there are mechanisms that induce lens from the ectoderm. Signaling pathways, molecular interactions and cell communication create the normal lens in the eye cup. It has the mechanisms to repair genetic and molecular damage from light. Also, this avascular tissue needs mechanisms to keep homeostasis. All these networks must restart if the tissue is injured or if it regenerates a part of it. During regeneration, all the cascades must be enabled again. In the past years, methods, such as microarrays, to analyze genes and gene expressions in a high-throughput approach have been utilized. Genes expressed in developing lens, lens during regeneration, aging lens and lens with cataract have been analyzed by these approaches. The purpose of this contribution is to summarize and compare the genomic analysis that has been performed in these different conditions. Most of the times, the data generated from this kind of analysis make it difficult to interpret and even more when different data sets are compared. Here, we have compared data sets from five different studies, and we have identified similar and different patterns between the different tested groups that were generated from genomic analysis.

\section{Analysis}

We have selected five papers dealing with microarray data and expressed sequence tag analysis. There are, of course, other papers in the literature that use highthroughput approaches to study gene expression in the lens [34]. However, we have decided to concentrate to these papers because of the conditions of the lens used (age-related cataract, Sparc-null mice and regenerating lens).

\section{Study \#1: 'Expressed sequence tag analysis of adult human lens for NEIBank Project: over 2000 non- redundant transcripts, novel genes and splice variants'} Two adult (40 years old) human lenses were used, and two libraries were created: (by) non normalized and (fs) normalized. Genes that are expressed in the lens or are abundant in the lens were found [175]. However, there was no mention of any comparison with other tissues. The data we used have been taken from the following tables of the paper:

- Table one: The twenty five most abundant transcripts in the unamplified lens library (by) 
- Table two: Cytoskeleton related transcripts from the combined lens libraries (by $+\mathrm{fs}$ )

- Table three: Oxidation related transcripts observed in by and fsEST collections

- Table four: Protease related transcripts

- Table five: Transcription factors

- Table six: Transcripts for growth factors, cytokines and growth factor related genes in lens libraries.

- Table seven: Apoptosis related transcripts in lens

\section{Study \#2: 'Expression profiling and gene discovery in the mouse lens'}

Mouse lenses of different ages and non-lens tissues to compare differentially regulated genes were used [176]. The data we used have been taken from the following tables of the paper:

- Table two: ONTO-express analysis of the 1,668 genes expressed at above background plus $2 \mathrm{SD}$ levels in at least one of the lens

- Table three: A list of the 50 most highly expressed genes identified in the lens samples

- Table four: Genes potentially preferentially expressed in lens compared to non lens samples as determined by $K$-means clustering

- Table six: Apoptosis genes expressed in the lens

- Table seven: Additional novel and uncharacterized genes expressed in the lens confirmed by Reverse transcription-Polymerase chain reaction (RT-PCR)

- Table eight: Additional known genes expressed in the lens confirmed by RT-PCR

\section{Study \#3: 'Gene expression changes during cataract progression in Sparc null mice: differential regulation of mouse globins in the lens'}

Microarray analysis of adult lenses from Sparc knockout mice on two strain backgrounds was used [177]. The data we used have been taken from the following tables of the paper:

- Table four: Confirmed genes: Nine month Sparc $^{\text {tm1cam }} 129 \mathrm{~Sv} / \mathrm{Ev}$ lenses versus $129 \mathrm{~Sv} / \mathrm{Ev}$ controls

- Table five: Confirmed genes: Nine month Sparc ${ }^{\text {tm1cam }} 129 /$ Ev/Mf1 ${ }^{\text {GPI-BB }}$ lenses versus Mf1 ${ }^{\text {GPI-BB }}$ controls

Study \#4: 'Identification and functional clustering of global gene expression differences between human age-related cataract and clear lenses'

Microarray analysis was used to find differences between age-related cataract and clear lenses in human [178].
The data we used have been taken from the following tables of the paper:

- Table one: Genes exhibiting differential expression in cataract relative to clear lenses

- Table continued: Genes exhibiting decreased expression in cataract relative to clear lenses

Study \#5: 'Gene expression and discovery during lens regeneration in mouse: regulation of epithelial to mesenchymal transition and lens differentiation'

Microarray analysis of mouse lens was used during regeneration after surgery [179]. The data we used have been taken from the following tables of the paper:

- Table one: Top 50 genes with the greatest increase in relative mRNA expression levels of regenerating lens compared to intact control lens 1, 2 and 3 weeks postextracapsular surgery. For a better visual presentation of the regulated genes at 1,2 and 3 weeks, the times that each gene is highest is marked in red.

- Table two: Top 50 genes with the greatest decrease in relative mRNA expression levels of regenerating lens compared to intact control lens 1, 2 and 3 weeks postextracapsular surgery. For a better visual presentation of the regulated genes at 1,2 and 3 weeks, the times that each gene is highest is marked in red.

- Table four: The gene cluster displaying a weak uniform increase in relative mRNA expression levels of regenerating lens compared to intact control lens 1, 2 and 3 weeks post-extracapsular surgery. For a better visual presentation of the regulated genes at 1,2 and 3 weeks, the times that each gene is highest is marked in red.

- Table six: The gene cluster displaying a strong uniform increase in relative mRNA expression levels of regenerating lens compared to intact control lens 1, 2 and 3 weeks post-extracapsular surgery. For a better visual presentation of the regulated genes at 1,2 and 3 weeks, the times that each gene is highest is marked in red.

- Table eight: The gene cluster displaying a strong increase in relative mRNA expression levels of regenerating lens compared to intact control lens 1 , 2 and 3 weeks post-extracapsular surgery. For a better visual presentation of the regulated genes at 1,2 and 3 weeks, the times that each gene is highest is marked in red.

- Table ten: The gene cluster displaying a weak decrease in relative mRNA expression levels of regenerating lens compared to intact control lens 1, 2 and 3 weeks postextracapsular surgery. For a better visual presentation of the regulated genes at 1, 2 and 3 weeks, the times that each gene is highest is marked in red. 
- Table twelve: The gene cluster displaying a strong uniform decrease in relative mRNA expression levels of regenerating lens compared to intact control lens 1, 2 and 3 weeks post-extracapsular surgery. For a better visual presentation of the regulated genes at 1, 2 and 3 weeks, the times that each gene is highest is marked in red.

\section{Presentation of analysis}

The data taken from the tables above were sorted and categorized depending on their expression in the different conditions that we examine. In our tables, the columns represent the following:

- Column 1: Name. Name of genes are the same with those taken from the tables of the different papers. If the same names were identified, they were fused in one row.

- Column 2: Accession number. Accession numbers are the ones from the selected papers. They can be from gene, protein or expressed sequence tags (EST) databases. If two or more genes (same gene, with a different name) are presented as one in a row, more accession numbers may appear in the corresponding column. In parenthesis are the new accession numbers that are assigned to the different genes, without omitting the old accession number from the original paper.

- Column 3: Lens. Genes found in the lens in general. Red, information from the paper 'Expressed sequence tag analysis of adult human lens for NEIBank Project: over 2000 non - redundant transcripts, novel genes and splice variants' [175]. Dark red, information from the paper 'Expression profiling and gene discovery in the mouse lens' [176] for genes that are not shown to be differentially expressed between lens and non-lens tissues.

- Column 4: More in lens. Genes that are found to be differentially expressed between lens and non-lens tissues. Red, information from the paper 'Expression profiling and gene discovery in the mouse lens' [176] for genes that are differentially expressed between lens and non-lens tissues. Yellow, information from the same paper but for genes that are not differentially expressed between lens and non-lens tissues.

- Column 5: Up in Sparc. Genes that are up-regulated in Sparc-null mice compared to normal controls. Red, information from the paper 'Gene expression changes during cataract progression in Sparc-null mice: differential regulation of mouse globins in the lens' [177].

- Column 6: Down in Sparc. Genes that are downregulated in Sparc-null mice compared to normal controls. Red, information from the paper 'Gene expression changes during cataract progression in Sparc-null mice: differential regulation of mouse globins in the lens' [177].

- Column 7: Up in cataract. Genes that are upregulated during age-related cataract compare to clear lenses. Red, information from the paper 'Identification and functional clustering of global gene expression differences between human agerelated cataract and clear lenses' [178].

- Column 8: Down in cataract. Genes that are down-regulated during age-related cataract compared to clear lenses. Red, information from the paper 'Identification and functional clustering of global gene expression differences between human age-related cataract and clear lenses' [178].

- Column 9: Up in regeneration. Genes that are up-regulated during lens regeneration compared to intact lenses. Red, information from the paper 'Gene expression and discovery during lens regeneration in mouse: regulation of epithelial to mesenchymal transition and lens differentiation' [179].

- Column 10: Down in regeneration. Genes that are down-regulated during lens regeneration compared to intact lenses. Red, information from the paper 'Gene expression and discovery during lens regeneration in mouse: regulation of epithelial to mesenchymal transition and lens differentiation' [179].

- Column 11 to 16 (Only present in Additional file 1: Table S2). Categories for gene functions. Red, if there was information from the five papers used.

\section{Discussion}

From the analysis we have performed, we have divided the regulated genes into eight major groups for our discussion.

\section{Crystallins-heat shock proteins}

Crystallins and heat shock proteins (Additional file 2: Table S4) comprise the main structural part of the lens. They have protective antioxidant properties and work as chaperones. Crystallins account for approximately $90 \%$ of total lens proteins [180]. They make the lens transparent in order for light to pass through and focus on the retina. Most of the different kinds of crystallins are present in the lens, as shown in Additional file 2: Table S4, column 3. Some of them are found up-regulated in the lens than in other tissues (crystallin beta A1, beta $\mathrm{A} 2$, gamma $\mathrm{A}$, gamma $\mathrm{C}$, gamma $\mathrm{E}$; Additional file 2: Table S4, column 4). During cataract, crystallins are disrupted; cross-linking between them results in aggregation, insolubility and opacification of the lens. Most of the crystallins are down-regulated during age-related 
cataract, as shown in Additional file 2: Table S4, column 6. Among them, crystallin alpha $A$ is a protein associated with known cases of cataract formation due to a mutation that results in an early stop codon in the gene [181] or other mutations that affect its interactions [182-189]. Furthermore, crystallin alpha B does not show any change during age-related cataract (Additional file 2: Table S4, columns 8 and 7), which is consistent with the fact that it has been shown to cause myopathy through other effects $[190,191]$. However, cataract has been associated with mutated crystallin alpha B in humans [192-196]. Beta crystallins are down-regulated during cataract (Additional file 2: Table S4, column 8), and they have a known role in cataract formation [197-215]. Crystallins gamma A and gamma $\mathrm{D}$ are also found in cataracts [216-234] and are downregulated during age-related cataract (Additional file 2: Table S4, column 8). Some of the crystallins are downregulated during regeneration of the lens from the lens capsule that is left behind, probably depending on the emergence of EMT in the early stages. Thus, crystallins that are found in mature lens, especially gamma crystallins, are down-regulated during regeneration (Additional file 2: Table S4, column 10). However, early crystallins are not up-regulated except a cytosolic thyroid hormonebinding protein, crystallin mu (Additional file 2: Table S4, column 9).

Heat shock proteins have structural and sequence similarities with crystallins and play transcriptional, structural and, most importantly, protective roles in the lens. Heat shock proteins are chaperones, and they protect the lens from oxidation and stress [235,236]. Some of them are found in the lens, as shown in Additional file 2: Table S4, column 3, but they do not seem to be significantly differentially expressed between the lens and other tissues (Additional file 2: Table S4, column 4). Similarly with crystallins, they are down-regulated during age-related cataract and regeneration (Additional file 2: Table S4, columns 8 and 10).

Overall, the comparison of the datasets clearly shows that crystallins malfunction during the different types of cataract except Sparc-related cataract. During agerelated cataract and regeneration, crystallins are mostly down-regulated. There is an apparent connection between cataract and crystallins from all the studies that are performed in this field. The data are consistent, and they link the abnormal regulation of crystallins as a key player for cataract formation (Additional file 3: Table S5).

\section{Cytochrome}

Cytochrome (Additional file 4: Table S6) is a protein related to electron transfer chain in the mitochondria, and it has been linked to stress [237]. Light induces stress response in the lens due to oxidation. This can be the reason why there are a lot of cytochrome oxidases present in the lens (Additional file 4: Table S6, column $3)$. The regulation of cytochrome oxidases is disrupted due to stress in the eye after surgically removing the lens fibers, a procedure that leads to regeneration-EMT response in the lens (Additional file 4: Table S6, columns 9 and 10).

Other than mitochondrial stress-related cytochrome oxidases, cytochromes of the P450 family seem to play a role in cataract formation. These proteins that are located in the endoplasmic reticulum can oxidize different kinds of substrates. Their regulation is disrupted similarly like cytochrome oxidases (Additional file 4: Table S6, columns 9 and 10). Studies show that cytochrome $\mathrm{P} 450$ is directly linked to cataract formation after metabolizing acetaminophen [238]. In addition, it is blamed for initiating cataract formation [239].

\section{Transcriptional factors}

Many transcriptional factors (Additional file 5: Table S7) are present in the lens, as shown in Additional file 5: Table S7, column 3. Many of them can be found in all tissues in order to maintain housekeeping functions (ATF4, apoptosis antagonizing transcription factor, bHLH transcriptional factors, general transcriptional factor II and III, and transcriptional elongation factors). Others, as discussed in the introduction, are transcriptional factors during development that define the different regions of the optic cup which, with appropriate interactions, create a functional eye. The expression of these transcriptional factors also persists after the eye is formed. The lens specific transcriptional factors define the lens epithelium, the transition zone and the lens fibers $[1,2,4]$. These, important for the integrity of the lens transcriptional factors, are not found in age- or Sparc-related cataract or regeneration (Additional file 5: Table S7, columns 5, 6, 7, 8, 9 and 10). Mutated transcriptional factors can result in cataract formation along with other effects, but these situations are not part of the cataract cases we examine, which are caused by age, the lack of a glycoprotein (Sparc) or the surgically removed lens fibers.

As mentioned earlier, studies implicate transcriptional factors with cataract formation. These studies include human patients. To sum up, transcriptional factors are difficult candidates in studying cataract formation during aging or EMT because they are involved in many different aspects of cell physiology.

\section{Immunity}

The lens is an avascular organ. Consequently, it is not in direct contact with blood flow. Thus, it is not surprising 
to see that proteins playing a role in the immune system are not expressed in the lens (Additional file 6: Table S8, column 3). However, two of them differentially show expression between the lens and other tissues (CD24 antigen and IL2-inducible T cell kinase; Additional file 6: Table S8, column 4). After surgically removing the lens fiber, which represents cataract formation through activation of EMT, many proteins that activate inflammation response, like complement components, are present, as seen in Additional file 6: Table S8, column 9. Interestingly a C5 antagonist has been found to be beneficial by inhibiting EMT in a lens regeneration model, even though the receptors involved are not known [240]. This implicates an inflammatory immune response [240]. On the other hand, during age-related cataract, there are a few proteins that are actually down-regulated (Additional file 6: Table S8, column 8), which might mean that the regulation of the immune system may play a role in maintaining the opacity of the lens. Sparc-null-related cataract shows up-regulation of complement components (Additional file 6: Table S8, column 5) that is linked to cell lysis, which is observed during Sparc-null cataract at the later stages.

Surgical removal of the lens fibers is a process that will trigger the immune system. The blood near the area of the damage brings molecules playing role in immune response. Also, white blood cells secrete other cytokines. These signals might promote the EMT process and play a role during age-related cataract. Oxidative stress is increasing with age, which in turn can trigger an inflammation response in neighboring tissues.

\section{Growth factors}

Growth factors (Additional file 7: Table S9) are small proteins that bind to certain receptors and activate specific downstream cascade events. Gradients of growth factors are regulating the correct gene expression and patterning in the lens $[1,3]$. All the major growth factors are present in the lens (Additional file 7: Table S9, column 3), and there is not much variation in expression during age- or Sparc-related cataract or regeneration (Additional file 7: Table S9, column 5, 6, 7, 8, 9 and 10). These molecules, if not produced in the lens, must diffuse from the other parts of the eye like the cornea and retina and pass through the extracellular matrix of the lens capsule in order to reach the lens epithelium or fibers. During aging, the lens capsule is changing, so the regulation in the capsular bag level is reduced. This disrupts the accommodation of the lens and can lead to presbyopia with age or interfere with metabolic processes in the lens $[153,171,241,242]$. FGFR proteins are very important for the lens to sense the FGF gradient in the optic cup and have known roles during cataract formation without showing any change during agerelated cataract (Additional file 7: Table S9, columns 7 and 8). TGFb, a molecule that plays the major role in EMT, and proteins that interact with it, such as latent TGFb-binding proteins, are up-regulated during regeneration (Additional file 7: Table S9, column 9). There might not be much about Sparc-null-related cataract and growth factor regulation (Additional file 7: Table S9, columns 5 and 6), but Sparc is a very important protein of the extracellular matrix. It can regulate various growth factors including FGF2, VEGF and PDGF [243]. This indicates that the cataractous lens might not differentially express growth factors, but it might respond differently to growth factors that reach the lens from other parts of the eye.

Overall, growth factors play an important role in cataract formation. They are directly implicated to secondary cataract formation through EMT where TGFb is the key player. For age-related cataract and Sparc-null cataract, growth factors seem to play a secondary role.

\section{Metalloproteinases/cathepsins}

In the lens, there is a lot of extracellular matrix, which has to be maintained in the appropriate proportion of proteins in order to serve its role as the first barrier for molecule trafficking. Extracellular matrix is replaced over time [244]. Metalloproteinases are proteins that can degrade extracellular matrix composed of collagen, fibrin, various receptors, etc. As shown in Additional file 8: Table S10, column 3, there are many kinds of metalloproteinases present in the lens. During regeneration, the lens epithelial cells proliferate and migrate in order to create again the fibers. In order for the remaining lens epithelial cells to accomplish that, they have to degrade the extracellular matrix that has covered all the area in the eye after the surgical operation. They also have known roles in regeneration in various systems [245-251]. Additional file 8: Table S10, column 9 shows metalloproteinases and cathepsins that are up-regulated during regeneration. On the other hand, tissue inhibitors of metalloproteinases are up-regulated too (Additional file 8: Table S10, column 9). The correct regulation of extracellular matrix degradation is essential for the regeneration of the lens. A not so well-known role of metalloproteinases is the relationship they have with cataract. There are reports showing that the disruption of normal regulation of metalloproteinases can lead to cataract [252-254]. As shown in Additional file 8: Table S10, column 8, some metalloproteinases are down-regulated during age-related cataract. Interestingly, expression of matrix metalloproteinases is not altered in Sparc-null cataract even though the composition of the extracellular matrix in these lenses is altered. 
Matrix metalloproteinases and cathepsins can be an area of investigation since they are found to be responsible for cataract formation. Inhibition of migration of epithelial cells after lens surgery can inhibit the formation of secondary cataract. In addition, maintaining the correct proportion of extracellular matrix around the lens is essential for the integrity and the ability of the lens to regulate outgoing signals.

\section{Collagen}

Some of the main components of the extracellular matrix of the lens are different types of collagens (Additional file 9: Table S1). These proteins are part of the capsular bag and are essential to maintain the integrity of the lens. Interestingly, there is only one type of collagen differentially expressed between the lens and non-lens tissues (Additional file 9: Table S1, column 4). Collagen proteins are down-regulated during Sparcrelated cataract, which might reflect an interaction between the Sparc glycoprotein (Additional file 9: Table S1, column 6). Sparc protein is very important when it comes to extracellular matrix. It can interact with collagen and other proteins of the extracellular matrix. It can also have an effect in the production of collagen. Thus, the Sparc-null lens make less collagen, which in turn can result in weaker lens capsule and disruption of its normal osmosis. Some collagen proteins are up-regulated during regeneration of the lens (Additional file 9: Table S1, column 9). Also, mutations in collagen genes have been shown to link with diseases, as discussed in the introduction.

\section{Ribosomal proteins - protein synthesis}

All the cells require ribosomal proteins and the protein synthesis machinery in order to create proteins that are needed for cell survival (Additional file 10: Table S3). It has been shown that there is differential regulation of these 'housekeeping' proteins, and they may have other roles in the cell for different conditions [255-257]. As shown in Additional file 10: Table S3, column 8, there are a lot of ribosomal proteins that are down-regulated during age-related cataract, which might reflect the disorganization of crucial networks leading to lens opacification. On the other hand, there are mitochondrial ribosomal proteins that are down-regulated during regeneration, which can reflect stress in the lens (Additional file 10: Table S3, column 10). Inactivation of ribosomal proteins S3, S8, S11 and of translation initiation factors is linked to the increase of life span in Caenorhabditis elegans, which means a possible energy conservation by controlling the rate of protein synthesis [258]. Such a mechanism might be more wide-spread in diseases as well.

\section{Additional files}

Additional file 1: Table S2. List of all genes and their expression in
different conditions of the lens.

Additional file 2: Table S4. List of genes related to crystallins and heat shock proteins and their expression in different conditions of the lens.

Additional file 3: Table S5. List of genes that are present in two or more different conditions of the lens.

Additional file 4: Table S6. List of genes related to cytochromes and their expression in different conditions of the lens.

Additional file 5: Table S7. List of genes related to transcriptional factors and their expression in different conditions of the lens.

Additional file 6: Table S8. List of genes related to immunity and their expression in different conditions of the lens.

Additional file 7: Table S9. List of genes related to growth factors and their expression in different conditions of the lens.

Additional file 8: Table S10. List of genes related to

metalloproteinases and cathepsins and their expression in different conditions of the lens.

Additional file 9: Table S1. List of genes related to collagen and their expression in different conditions of the lens.

Additional file 10: Table S3. List of genes related to ribosomal proteins and translation and their expression in different conditions of the lens.

\section{Competing interests}

The authors declare that they have no competing interests.

\section{Authors' contributions}

KS and PAT conceived the idea, analyzed the data and co-wrote the paper. Both authors read and approved the final manuscript.

\section{Acknowledgments}

This work was supported by NIH grant EY16707 to PAT.

Received: 10 May 2012 Accepted: 14 May 2012

Published: 1 September 2012

\section{References}

1. Donner AL, Lachke SA, Maas RL: Lens induction in vertebrates: variations on a conserved theme of signaling events. Semin Cell Dev Biol 2006, 17(6):676-685.

2. Fuhrmann S: Eye morphogenesis and patterning of the optic vesicle. Curr Top Dev Biol 2010, 93:61-84.

3. Lovicu FJ, McAvoy JW: Growth factor regulation of lens development. Dev Biol 2005, 280(1):1-14.

4. Chow RL, Lang RA: Early eye development in vertebrates. Annu Rev Cell Dev Biol 2001, 17:255-296.

5. Lang RA: Which factors stimulate lens fiber cell differentiation in vivo? Invest Ophthalmol Vis Sci 1999, 40(13):3075-3078.

6. Grainger RM, Henry JJ, Saha MS, Servetnick M: Recent progress on the mechanisms of embryonic lens formation. Eye (Lond) 1992, 6(Pt 2):117-122.

7. Lang RA: Pathways regulating lens induction in the mouse. Int J Dev Biol 2004, 48(8-9):783-791.

8. Cvekl A, Kashanchi F, Sax CM, Brady JN, Piatigorsky J: Transcriptional regulation of the mouse alpha $A$-crystallin gene: activation dependent on a cyclic AMP-responsive element (DE1/CRE) and a Pax-6-binding site. Mol Cell Biol 1995, 15(2):653-660.

9. Cvekl A, Sax CM, Bresnick EH, Piatigorsky J: A complex array of positive and negative elements regulates the chicken alpha A-crystallin gene: involvement of Pax-6, USF, CREB and/or CREM, and AP-1 proteins. Mol Cell Biol 1994, 14(11):7363-7376.

10. Cvekl A, Sax CM, Li X, McDermott JB, Piatigorsky J: Pax-6 and lens-specific transcription of the chicken delta 1-crystallin gene. Proc Natl Acad Sci U S A 1995, 92(10):4681-4685. 
11. Duncan MK, Haynes JI 2nd, Cvekl A, Piatigorsky J: Dual roles for Pax-6: a transcriptional repressor of lens fiber cell-specific beta-crystallin genes. Mol Cell Biol 1998, 18(9):5579-5586.

12. Grindley JC, Davidson DR, Hill RE: The role of Pax-6 in eye and nasal development. Development 1995, 121(5):1433-1442.

13. Li H, Tierney C, Wen L, Wu JY, Rao Y: A single morphogenetic field gives rise to two retina primordia under the influence of the prechordal plate. Development 1997, 124(3):603-615.

14. Richardson J, Cvekl A, Wistow G: Pax-6 is essential for lens-specific expression of zeta-crystallin. Proc Natl Acad Sci U S A 1995, 92(10):4676-4680.

15. Walther C, Gruss P: Pax-6, a murine paired box gene, is expressed in the developing CNS. Development 1991, 113(4):1435-1449.

16. Smith AN, Miller LA, Radice G, Ashery-Padan R, Lang RA: Stage-dependent modes of Pax6-Sox2 epistasis regulate lens development and eye morphogenesis. Development 2009, 136(17):2977-2985.

17. Liu W, Lagutin OV, Mende M, Streit A, Oliver G: Six3 activation of Pax6 expression is essential for mammalian lens induction and specification. EMBO J 2006, 25(22):5383-5395

18. Kroeber M, Davis N, Holzmann S, Kritzenberger M, Shelah-Goraly M, Ofri R, Ashery-Padan R, Tamm ER: Reduced expression of Pax6 in lens and cornea of mutant mice leads to failure of chamber angle development and juvenile glaucoma. Hum Mol Genet 2010, 19(17):3332-3342.

19. Plageman TF Jr, Chung MI, Lou M, Smith AN, Hildebrand JD, Wallingford JB, Lang RA: Pax6-dependent Shroom3 expression regulates apical constriction during lens placode invagination. Development 2010, 137:405-415.

20. Ashery-Padan R, Gruss P: Pax6 lights-up the way for eye development. Curr Opin Cell Biol 2001, 13(6):706-714.

21. Canto-Soler MV, Adler R: Optic cup and lens development requires Pax6 expression in the early optic vesicle during a narrow time window. Dev Biol 2006, 294(1):119-132.

22. Chanas SA, Collinson JM, Ramaesh T, Dora N, Kleinjan DA, Hill RE, West JD: Effects of elevated Pax6 expression and genetic background on mouse eye development. Invest Ophthalmol Vis Sci 2009, 50(9):4045-4059.

23. Cui W, Tomarev SI, Piatigorsky J, Chepelinsky AB, Duncan MK: Mafs, Prox1, and Pax6 can regulate chicken betaB1-crystallin gene expression. J Biol Chem 2004, 279(12):11088-11095.

24. Davis-Silberman N, Kalich T, Oron-Karni V, Marquardt T, Kroeber M, Tamm ER, Ashery-Padan R: Genetic dissection of Pax6 dosage requirements in the developing mouse eye. Hum Mol Genet 2005, 14(15):2265-2276.

25. Duncan MK, Xie L, David LL, Robinson ML, Taube JR, Cui W, Reneker LW: Ectopic Pax6 expression disturbs lens fiber cell differentiation. Invest Ophthalmol Vis Sci 2004, 45(10):3589-3598.

26. Inoue M, Kamachi Y, Matsunami H, Imada K, Uchikawa M, Kondoh H: PAX6 and SOX2-dependent regulation of the Sox2 enhancer N-3 involved in embryonic visual system development. Genes Cells 2007, 12(9):1049-1061.

27. Kim J, Lauderdale JD: Overexpression of pairedless Pax6 in the retina disrupts corneal development and affects lens cell survival. Dev Biol 2008, 313(1):434-454.

28. Kondoh H, Uchikawa M, Kamachi Y: Interplay of Pax6 and SOX2 in lens development as a paradigm of genetic switch mechanisms for cell differentiation. Int J Dev Biol 2004, 48(8-9):819-827.

29. Lesaffre B, Joliot A, Prochiantz A, Volovitch M: Direct non-cell autonomous Pax6 activity regulates eye development in the zebrafish. Neural Dev 2007, 2:2.

30. Li S, Goldowitz D, Swanson DJ: The requirement of pax6 for postnatal eye development: evidence from experimental mouse chimeras. Invest Ophthalmol Vis Sci 2007, 48(7):3292-3300.

31. Muta M, Kamachi $Y$, Yoshimoto A, Higashi $Y$, Kondoh $\mathrm{H}$ : Distinct roles of SOX2, Pax6 and Maf transcription factors in the regulation of lens-specific delta1-crystallin enhancer. Genes Cells 2002, 7(8):791-805.

32. Purcell P, Oliver G, Mardon G, Donner AL, Maas RL: Pax6-dependence of Six3, Eya1 and Dach1 expression during lens and nasal placode induction. Gene Expr Patterns 2005, 6(1):110-118.

33. Shaham O, Smith AN, Robinson ML, Taketo MM, Lang RA, Ashery-Padan R: Pax6 is essential for lens fiber cell differentiation. Development 2009, 136(15):2567-2578.

34. Wolf LV, Yang Y, Wang J, Xie Q, Braunger B, Tamm ER, Zavadil J, Cvekl A: Identification of pax6-dependent gene regulatory networks in the mouse lens. PLoS One 2009, 4(1):e4159.
35. Yang $Y$, Cvekl A: Tissue-specific regulation of the mouse alphaA-crystallin gene in lens via recruitment of Pax6 and c-Maf to its promoter. J Mol Biol 2005, 351(3):453-469.

36. Zygar CA, Cook TL, Grainger RM Jr: Gene activation during early stages of lens induction in Xenopus. Development 1998, 125(17):3509-3519.

37. Kamachi Y, Sockanathan S, Liu Q, Breitman M, Lovell-Badge R, Kondoh H: Involvement of SOX proteins in lens-specific activation of crystallin genes. EMBO J 1995, 14(14):3510-3519.

38. Kamachi $Y$, Uchikawa M, Collignon J, Lovell-Badge $\mathrm{R}$, Kondoh $\mathrm{H}$ : Involvement of Sox1, 2 and 3 in the early and subsequent molecular events of lens induction. Development 1998, 125(13):2521-2532.

39. Kamachi Y, Uchikawa M, Tanouchi A, Sekido R, Kondoh H: Pax6 and SOX2 form a co-DNA-binding partner complex that regulates initiation of lens development. Genes Dev 2001, 15(10):1272-1286.

40. Koster RW, Kuhnlein RP, Wittbrodt J: Ectopic Sox3 activity elicits sensory placode formation. Mech Dev 2000, 95(1-2):175-187.

41. Nishiguchi S, Wood H, Kondoh H, Lovell-Badge R, Episkopou V: Sox1 directly regulates the gamma-crystallin genes and is essential for lens development in mice. Genes Dev 1998, 12(6):776-781.

42. Donner AL, Episkopou V, Maas RL: Sox2 and Pou2f1 interact to control lens and olfactory placode development. Dev Biol 2007, 303(2):784-799.

43. Shimada N, Aya-Murata T, Reza HM, Yasuda K: Cooperative action between L-Maf and Sox2 on delta-crystallin gene expression during chick lens development. Mech Dev 2003, 120(4):455-465

44. Loosli F, Koster RW, Carl M, Krone A, Wittbrodt J: Six3, a medaka homologue of the Drosophila homeobox gene sine oculis is expressed in the anterior embryonic shield and the developing eye. Mech Dev 1998, 74(1-2):159-164

45. Oliver G, Loosli F, Koster R, Wittbrodt J, Gruss P: Ectopic lens induction in fish in response to the murine homeobox gene Six3. Mech Dev 1996, 60(2):233-239.

46. Oliver G, Mailhos A, Wehr R, Copeland NG, Jenkins NA, Gruss P: Six3, a murine homologue of the sine oculis gene, demarcates the most anterior border of the developing neural plate and is expressed during eye development. Development 1995, 121(12):4045-4055.

47. Dutta S, Dietrich JE, Aspock G, Burdine RD, Schier A, Westerfield M, Varga ZM: pitx3 defines an equivalence domain for lens and anterior pituitary placode. Development 2005, 132(7):1579-1590.

48. Ho HY, Chang KH, Nichols J, Li M: Homeodomain protein Pitx3 maintains the mitotic activity of lens epithelial cells. Mech Dev 2009,

126(1-2):18-29.

49. Khosrowshahian F, Wolanski M, Chang WY, Fujiki K, Jacobs L, Crawford MJ: Lens and retina formation require expression of Pitx3 in Xenopus pre-lens ectoderm. Dev Dyn 2005, 234(3):577-589.

50. Medina-Martinez $\mathrm{O}$, Shah $\mathrm{R}$, Jamrich M: Pitx3 controls multiple aspects of lens development. Dev Dyn 2009, 238(9):2193-2201.

51. Qiu HY, Guo C, Cheng XW, Huang Y, Xiong ZQ, Ding YQ: Pitx3-CreER mice showing restricted Cre expression in developing ocular lens and skeletal muscles. Genesis 2008, 46(6):324-328.

52. Shi X, Bosenko DV, Zinkevich NS, Foley S, Hyde DR, Semina EV, Vihtelic TS: Zebrafish pitx3 is necessary for normal lens and retinal development. Mech Dev 2005, 122(4):513-527.

53. Shi X, Luo Y, Howley S, Dzialo A, Foley S, Hyde DR, Vihtelic TS: Zebrafish foxe3: roles in ocular lens morphogenesis through interaction with pitx3. Mech Dev 2006, 123(10):761-782.

54. Zilinski CA, Shah $R$, Lane ME, Jamrich M: Modulation of zebrafish pitx3 expression in the primordia of the pituitary, lens, olfactory epithelium and cranial ganglia by hedgehog and nodal signaling. Genesis 2005, 41(1):33-40

55. Chen X, Taube JR, Simirskii VI, Patel TP, Duncan MK: Dual roles for Prox1 in the regulation of the chicken betaB1-crystallin promoter. Invest Ophthalmol Vis Sci 2008, 49(4):1542-1552.

56. Duncan MK, Cui W, Oh DJ, Tomarev SI: Prox1 is differentially localized during lens development. Mech Dev 2002, 112(1-2):195-198.

57. Lengler J, Krausz E, Tomarev S, Prescott A, Quinlan RA, Graw J: Antagonistic action of Six3 and Prox1 at the gamma-crystallin promoter. Nucleic Acids Res 2001, 29(2):515-526.

58. Rodriguez-Niedenfuhr M, Papoutsi M, Christ B, Nicolaides $\mathrm{KH}$, von Kaisenberg CS, Tomarev SI, Wilting J: Prox 1 is a marker of ectodermal placodes, endodermal compartments, lymphatic endothelium and lymphangioblasts. Anat Embryol (Berl) 2001, 204(5):399-406. 
59. Tomarev SI, Zinovieva RD, Chang B, Hawes NL: Characterization of the mouse Prox1 gene. Biochem Biophys Res Commun 1998, 248(3):684-689.

60. Wigle JT, Chowdhury K, Gruss P, Oliver G: Prox1 function is crucial for mouse lens-fibre elongation. Nat Genet 1999, 21(3):318-322.

61. Blixt A, Mahlapuu M, Aitola M, Pelto-Huikko M, Enerback S, Carlsson P: A forkhead gene, FoxE3, is essential for lens epithelial proliferation and closure of the lens vesicle. Genes Dev 2000, 14(2):245-254.

62. Brownell I, Dirksen M, Jamrich M: Forkhead Foxe3 maps to the dysgenetic lens locus and is critical in lens development and differentiation. Genesis 2000, 27(2):81-93.

63. Dimanlig PV, Faber SC, Auerbach W, Makarenkova HP, Lang RA: The upstream ectoderm enhancer in Pax6 has an important role in lens induction. Development 2001, 128(22):4415-4424.

64. Kenyon KL, Moody SA, Jamrich M: A novel fork head gene mediates early steps during Xenopus lens formation. Development 1999, 126(22):5107-5116.

65. Ishibashi S, Yasuda K: Distinct roles of maf genes during Xenopus lens development. Mech Dev 2001, 101(1-2):155-166.

66. Kawauchi S, Takahashi S, Nakajima O, Ogino H, Morita M, Nishizawa M, Yasuda K, Yamamoto M: Regulation of lens fiber cell differentiation by transcription factor c-Maf. J Biol Chem 1999, 274(27):19254-19260.

67. Kim JI, Li T, Ho IC, Grusby MJ, Glimcher LH: Requirement for the c-Maf transcription factor in crystallin gene regulation and lens development. Proc Natl Acad Sci U S A 1999, 96(7):3781-3785.

68. Ogino $H$, Yasuda K: Induction of lens differentiation by activation of a bZIP transcription factor, L-Maf. Science 1998, 280(5360):115-118.

69. Ring BZ, Cordes SP, Overbeek PA, Barsh GS: Regulation of mouse lens fiber cell development and differentiation by the Maf gene. Development 2000, 127(2):307-317.

70. Civil A, van Genesen ST, Lubsen NH: c-Maf, the gammaD-crystallin Mafresponsive element and growth factor regulation. Nucleic Acids Res 2002, 30(4):975-982.

71. Faber SC, Dimanlig P, Makarenkova HP, Shirke S, Ko K, Lang RA: Fgf receptor signaling plays a role in lens induction. Development 2001, 128 (22):4425-4438.

72. McAvoy JW, Chamberlain CG, de longh RU, Richardson NA, Lovicu FJ: The role of fibroblast growth factor in eye lens development. Ann N Y Acad Sci 1991, 638:256-274.

73. Chamberlain CG, McAvoy JW: Evidence that fibroblast growth factor promotes lens fibre differentiation. Curr Eye Res 1987, 6(9):1165-1169.

74. Chamberlain CG, MCAvoy JW: Induction of lens fibre differentiation by acidic and basic fibroblast growth factor (FGF). Growth Factors 1989, 1(2):125-134.

75. McAvoy JW, Chamberlain CG: Fibroblast growth factor (FGF) induces different responses in lens epithelial cells depending on its concentration. Development 1989, 107(2):221-228.

76. Lovicu FJ, McAvoy JW: Structural analysis of lens epithelial explants induced to differentiate into fibres by fibroblast growth factor (FGF). Exp Eye Res 1989, 49(3):479-494.

77. Lovicu FJ, McAvoy JW: The age of rats affects the response of lens epithelial explants to fibroblast growth factor. An ultrastructural analysis. Invest Ophthalmol Vis Sci 1992, 33(7):2269-2278.

78. Kok A, Lovicu FJ, Chamberlain CG, McAvoy JW: Influence of platelet-derived growth factor on lens epithelial cell proliferation and differentiation. Growth Factors 2002, 20(1):27-34

79. de longh R, McAvoy JW: Distribution of acidic and basic fibroblast growth factors (FGF) in the foetal rat eye: implications for lens development. Growth Factors 1992, 6(2):159-177.

80. de longh R, McAvoy JW: Spatio-temporal distribution of acidic and basic FGF indicates a role for FGF in rat lens morphogenesis. Dev Dyn 1993, 198(3):190-202.

81. Schulz MW, Chamberlain CG, de longh RU, McAvoy JW: Acidic and basic FGF in ocular media and lens: implications for lens polarity and growth patterns. Development 1993, 118(1):117-126.

82. Le AC, Musil LS: A novel role for FGF and extracellular signal-regulated kinase in gap junction-mediated intercellular communication in the lens. J Cell Biol 2001, 154(1):197-216.

83. Le AC, Musil LS: FGF signaling in chick lens development. Dev Biol 2001, 233(2):394-411.

84. Vogel-Hopker A, Momose T, Rohrer H, Yasuda K, Ishihara L, Rapaport DH: Multiple functions of fibroblast growth factor-8 (FGF-8) in chick eye development. Mech Dev 2000, 94(1-2):25-36.
85. Lovicu FJ, Overbeek PA: Overlapping effects of different members of the FGF family on lens fiber differentiation in transgenic mice. Development 1998, 125(17):3365-3377

86. Robinson ML, Ohtaka-Maruyama C, Chan CC, Jamieson S, Dickson C, Overbeek PA, Chepelinsky AB: Disregulation of ocular morphogenesis by lens-specific expression of FGF-3/int-2 in transgenic mice. Dev Biol 1998, 198(1):13-31.

87. Robinson ML, Overbeek PA, Verran DJ, Grizzle WE, Stockard CR, Friesel R, Maciag T, Thompson JA: Extracellular FGF-1 acts as a lens differentiation factor in transgenic mice. Development 1995, 121(2):505-514.

88. Garcia CM, Huang J, Madakashira BP, Liu Y, Rajagopal R, Dattilo L, Robinson $\mathrm{ML}$, Beebe DC: The function of FGF signaling in the lens placode. Dev Biol 2011, 351(1):176-185.

89. Qu X, Hertzler K, Pan Y, Grobe K, Robinson ML, Zhang X: Genetic epistasis between heparan sulfate and FGF-Ras signaling controls lens development. Dev Biol 2011, 355:12-20.

90. Smith AN, Radice G, Lang RA: Which FGF ligands are involved in lens induction? Dev Biol 2010, 337(2):195-198.

91. Garcia CM, Yu K, Zhao H, Ashery-Padan R, Ornitz DM, Robinson ML, Beebe $D C$ : Signaling through FGF receptor-2 is required for lens cell survival and for withdrawal from the cell cycle during lens fiber cell differentiation. Dev Dyn 2005, 233(2):516-527.

92. Bailey AP, Bhattacharyya S, Bronner-Fraser M, Streit A: Lens specification is the ground state of all sensory placodes, from which FGF promotes olfactory identity. Dev Cell 2006, 11(4):505-517.

93. Pan Y, Woodbury A, Esko JD, Grobe K, Zhang X: Heparan sulfate biosynthetic gene Ndst1 is required for FGF signaling in early lens development. Development 2006, 133(24):4933-4944.

94. Robinson ML: An essential role for FGF receptor signaling in lens development. Semin Cell Dev Biol 2006, 17(6):726-740.

95. lyengar L, Wang Q, Rasko JE, McAvoy JW, Lovicu FJ: Duration of ERK1/2 phosphorylation induced by FGF or ocular media determines lens cell fate. Differentiation 2007, 75(7):662-668.

96. Tholozan FM, Gribbon C, Li Z, Goldberg MW, Prescott AR, McKie N, Quinlan RA: FGF-2 release from the lens capsule by MMP-2 maintains lens epithelial cell viability. Mol Biol Cell 2007, 18(11):4222-4231.

97. Boswell BA, Overbeek PA, Musil LS: Essential role of BMPs in FGF-induced secondary lens fiber differentiation. Dev Biol 2008, 324(2):202-212.

98. Loren CE, Schrader JW, Ahlgren U, Gunhaga L: FGF signals induce Caprin2 expression in the vertebrate lens. Differentiation 2009, 77(4):386-394.

99. Saravanamuthu SS, Gao CY, Zelenka PS: Notch signaling is required for lateral induction of Jagged1 during FGF-induced lens fiber differentiation. Dev Biol 2009, 332(1):166-176.

100. de longh RU, Lovicu FJ, Hanneken A, Baird A, McAvoy JW: FGF receptor-1 (flg) expression is correlated with fibre differentiation during rat lens morphogenesis and growth. Dev Dyn 1996, 206(4):412-426.

101. Robinson ML, MacMillan-Crow LA, Thompson JA, Overbeek PA: Expression of a truncated FGF receptor results in defective lens development in transgenic mice. Development 1995, 121(12):3959-3967.

102. Chow RL, Roux GD, Roghani M, Palmer MA, Rifkin DB, Moscatelli DA, Lang RA: FGF suppresses apoptosis and induces differentiation of fibre cells in the mouse lens. Development 1995, 121(12):4383-4393.

103. Stolen CM, Griep AE: Disruption of lens fiber cell differentiation and survival at multiple stages by region-specific expression of truncated FGF receptors. Dev Biol 2000, 217(2):205-220.

104. Govindarajan V, Overbeek PA: Secreted FGFR3, but not FGFR1, inhibits lens fiber differentiation. Development 2001, 128(9):1617-1627.

105. Zhao H, Yang T, Madakashira BP, Thiels CA, Bechtle CA, Garcia CM, Zhang H, Yu K, Ornitz DM, Beebe DC, Robinson ML: Fibroblast growth factor receptor signaling is essential for lens fiber cell differentiation. Dev Biol 2008, 318(2):276-288.

106. Dudley AT, Lyons KM, Robertson EJ: A requirement for bone morphogenetic protein-7 during development of the mammalian kidney and eye. Genes Dev 1995, 9(22):2795-2807.

107. Furuta $Y$, Hogan BL: BMP4 is essential for lens induction in the mouse embryo. Genes Dev 1998, 12(23):3764-3775.

108. Wawersik S, Purcell P, Rauchman M, Dudley AT, Robertson EJ, Maas R: BMP7 acts in murine lens placode development. Dev Biol 1999, 207(1): $176-188$. 
109. Morcillo J, Martinez-Morales JR, Trousse F, Fermin Y, Sowden JC, Bovolenta P: Proper patterning of the optic fissure requires the sequential activity of BMP7 and SHH. Development 2006, 133(16):3179-3190.

110. Faber SC, Robinson ML, Makarenkova HP, Lang RA: Bmp signaling is required for development of primary lens fiber cells. Development 2002, 129(15):3727-3737.

111. de longh RU, Lovicu FJ, Overbeek PA, Schneider MD, Joya J, Hardeman ED, McAvoy JW: Requirement for TGFbeta receptor signaling during terminal lens fiber differentiation. Development 2001, 128(20):3995-4010.

112. de longh RU, Chen Y, Kokkinos MI, McAvoy JW: BMP and activin receptor expression in lens development. Mol Vis 2004, 10:566-576.

113. Hosler MR, Wang-Su ST, Wagner BJ: Role of the proteasome in TGF-beta signaling in lens epithelial cells. Invest Ophthalmol Vis Sci 2006, 47(5): 2045-2052.

114. Sjodal M, Edlund T, Gunhaga L: Time of exposure to BMP signals plays a key role in the specification of the olfactory and lens placodes ex vivo. Dev Cell 2007, 13(1):141-149.

115. Kim YS, Kim NH, Jung DH, Jang DS, Lee YM, Kim JM, Kim JS: Genistein inhibits aldose reductase activity and high glucose-induced TGF-beta2 expression in human lens epithelial cells. Eur J Pharmacol 2008, 594 (1-3):18-25.

116. Rajagopal R, Dattilo LK, Kaartinen V, Deng CX, Umans L, Zwijsen A, Roberts $A B$, Bottinger EP, Beebe DC: Functions of the type 1 BMP receptor Acvr 1 (Alk2) in lens development: cell proliferation, terminal differentiation, and survival. Invest Ophthalmol Vis Sci 2008, 49(11):4953-4960.

117. Rajagopal R, Huang J, Dattilo LK, Kaartinen V, Mishina Y, Deng CX, Umans L, Zwijsen A, Roberts AB, Beebe DC: The type I BMP receptors, Bmpr1a and Acvr1, activate multiple signaling pathways to regulate lens formation. Dev Biol 2009, 335(2):305-316.

118. Blakely EA, Bjornstad KA, Chang PY, McNamara MP, Chang E, Aragon G, Lin $S P$, Lui G, Polansky JR: Growth and differentiation of human lens epithelial cells in vitro on matrix. Invest Ophthalmol Vis Sci 2000, 41 (12):3898-3907.

119. McAvoy JW: The spatial relationship between presumptive lens and optic vesicle/cup during early eye morphogenesis in the rat. Exp Eye Res 1981, 33(4):447-458

120. Parmigiani CM, McAvoy JW: The roles of laminin and fibronectin in the development of the lens capsule. Curr Eye Res 1991, 10(6):501-511.

121. Wakely J: Scanning electron microscope study of the extracellular matrix between presumptive lens and presumptive retina of the chick embryo. Anat Embryol (Berl) 1977, 150(2):163-170.

122. Walker JL, Zhang L, Menko AS: A signaling role for the uncleaved form of alpha 6 integrin in differentiating lens fiber cells. Dev Biol 2002, 251 (2):195-205.

123. Walker JL, Zhang L, Menko AS: Transition between proliferation and differentiation for lens epithelial cells is regulated by Src family kinases. Dev Dyn 2002, 224(4):361-372.

124. Zuk A, Hay ED: Expression of beta 1 integrins changes during transformation of avian lens epithelium to mesenchyme in collagen gels. Dev Dyn 1994, 201(4):378-393.

125. Piatigorsky J: Insulin initiation of lens fiber differentiation in culture: elongation of embryonic lens epithelial cells. Dev Biol 1973, 30(1): 214-216.

126. Piatigorsky J, Rothschild SS, Wollberg M: Stimulation by insulin of cell elongation and microtubule assembly in embryonic chick-lens epithelia. Proc Natl Acad Sci U S A 1973, 70(4):1195-1198.

127. Beebe DC, Silver MH, Belcher KS, Van Wyk JJ, Svoboda ME, Zelenka PS: Lentropin, a protein that controls lens fiber formation, is related functionally and immunologically to the insulin-like growth factors. Proc Natl Acad Sci U S A 1987, 84(8):2327-2330.

128. Ohtaka-Maruyama C, Wang X, Ge H, Chepelinsky AB: Overlapping Sp1 and AP2 binding sites in a promoter element of the lens-specific MIP gene. Nucleic Acids Res 1998, 26(2):407-414.

129. Lengler J, Bittner T, Munster D: Gawad Ael D, Graw J: Agonistic and antagonistic action of AP2, Msx2, Pax6, Prox1 AND Six3 in the regulation of Sox2 expression. Ophthalmic Res 2005, 37(6):301-309.

130. Harding JJ: Post-translational modification of lens proteins in cataract. Lens Eye Toxic Res 1991, 8(2-3):245-250.

131. Congdon N, Broman KW, Lai H, Munoz B, Bowie H, Gilber D, Wojciechowski R, Alston C, West SK: Nuclear cataract shows significant familial aggregation in an older population after adjustment for possible shared environmental factors. Invest Ophthalmol Vis Sci 2004, 45(7):2182-2186.

132. Chatterjee A, Milton RC, Thyle S: Prevalence and aetiology of cataract in Punjab. Br J Ophthalmol 1982, 66(1):35-42

133. Arnarsson A, Jonasson F, Sasaki H, Ono M, Jonsson V, Kojima M, Katoh N Sasaki K, Reykjavik Eye Study Group: Risk factors for nuclear lens opacification: the Reykjavik Eye Study. Dev Ophthalmol 2002, 35:12-20.

134. West SK, Valmadrid CT: Epidemiology of risk factors for age-related cataract. Surv Ophthalmol 1995, 39(4):323-334.

135. Hejtmancik JF, Kantorow M: Molecular genetics of age-related cataract. Exp Eye Res 2004, 79(1):3-9.

136. Semina EV, Ferrell RE, Mintz-Hittner HA, Bitoun P, Alward WL, Reiter RS, Funkhauser C, Daack-Hirsch S, Murray JC: A novel homeobox gene PITX3 is mutated in families with autosomal-dominant cataracts and ASMD. Nat Genet 1998, 19(2):167-170.

137. Hejtmancik JF: Congenital cataracts and their molecular genetics. Semin Cell Dev Biol 2008, 19(2):134-149.

138. Ammash NM, Sundt TM, Connolly HM: Marfan syndrome-diagnosis and management. Curr Probl Cardiol 2008, 33(1):7-39.

139. Aragon-Martin JA, Ritch R, Liebmann J, O'Brien C, Blaaow K, Mercieca F, Spiteri A, Cobb CJ, Damji KF, Tarkkanen A, Rezaie T, Child AH, Sarfarazi M: Evaluation of LOXL1 gene polymorphisms in exfoliation syndrome and exfoliation glaucoma. Mol Vis 2008, 14:533-541.

140. Mossbock G, Renner W, Faschinger C, Schmut O, Wedrich A, Weger M: Lysyl oxidase-like protein 1 (LOXL1) gene polymorphisms and exfoliation glaucoma in a Central European population. Mol Vis 2008, 14:857-861.

141. Thorleifsson G, Magnusson KP, Sulem P, Walters GB, Gudbjartsson DF, Stefansson $H$, Jonsson $T$, Jonasdottir A, Jonasdottir A, Stefansdottir $G$, Masson G, Hardarson GA, Petursson H, Arnarsson A, Motallebipour M, Wallerman O, Wadelius C, Gulcher JR, Thorsteinsdottir U, Kong A, Jonasson F, Stefansson K: Common sequence variants in the LOXL1 gene confer susceptibility to exfoliation glaucoma. Science 2007, 317(5843):1397-1400.

142. Zenker M, Aigner T, Wendler O, Tralau T, Muntefering H, Fenski R, Pitz S, Schumacher V, Royer-Pokora B, Wühl E, Cochat P, Bouvier R, Kraus C, Mark K, Madlon H, Dötsch J, Rascher W, Maruniak-Chudek I, Lennert T, Neumann $L M$, Reis A: Human laminin beta2 deficiency causes congenital nephrosis with mesangial sclerosis and distinct eye abnormalities. Hum Mol Genet 2004, 13(21):2625-2632.

143. Van Agtmael T, Schlotzer-Schrehardt U, McKie L, Brownstein DG, Lee AW, Cross SH, Sado Y, Mullins JJ, Pöschl E, Jackson IJ: Dominant mutations of Col4a1 result in basement membrane defects which lead to anterior segment dysgenesis and glomerulopathy. Hum Mol Genet 2005, 14(21):3161-3168

144. Colville DJ, Savige J: Alport syndrome. A review of the ocular manifestations. Ophthalmic Genet 1997, 18(4):161-173.

145. lozzo RV: Basement membrane proteoglycans: from cellar to ceiling. Nat Rev Mol Cell Biol 2005, 6(8):646-656.

146. Lee $\mathrm{EH}$, Joo CK: Role of transforming growth factor-beta in transdifferentiation and fibrosis of lens epithelial cells. Invest Ophthalmol Vis Sci 1999, 40(9):2025-2032

147. Gilmour DT, Lyon GJ, Carlton MB, Sanes JR, Cunningham JM, Anderson JR Hogan BL, Evans MJ, Colledge WH: Mice deficient for the secreted glycoprotein SPARC/osteonectin/BM40 develop normally but show severe age-onset cataract formation and disruption of the lens. EMBO J 1998, 17(7):1860-1870.

148. Yan Q, Clark JI, Wight TN, Sage EH: Alterations in the lens capsule contribute to cataractogenesis in SPARC-null mice. J Cell Sci 2002, 115 (Pt 13):2747-2756.

149. Greenburg G, Hay ED: Epithelia suspended in collagen gels can lose polarity and express characteristics of migrating mesenchymal cells. J Cell Biol 1982, 95(1):333-339.

150. Zuk A, Kleinman HK, Hay ED: Culture on basement membrane does not reverse the phenotype of lens derived mesenchyme-like cells. Int J Dev Biol 1989, 33(4):487-490.

151. de longh RU, Wederell E, Lovicu FJ, McAvoy JW: Transforming growth factor-beta-induced epithelial-mesenchymal transition in the lens: a model for cataract formation. Cells Tissues Organs 2005, 179(1-2):43-55.

152. Tamiya S, Wormstone IM, Marcantonio JM, Gavrilovic J, Duncan G: Induction of matrix metalloproteinases 2 and 9 following stress to the lens. Exp Eye Res 2000, 71(6):591-597. 
153. Danysh BP, Duncan MK: The lens capsule. Exp Eye Res 2009, 88(2): 151-164.

154. Martinez $\mathrm{G}$, de longh RU: The lens epithelium in ocular health and disease. Int J Biochem Cell Biol 2010, 42(12):1945-1963.

155. Kyselova Z, Stefek M, Bauer V: Pharmacological prevention of diabetic cataract. J Diabetes Complications 2004, 18(2):129-140.

156. Aksoy H, Keles S, Kocer I, Akcay F: Diabetic cataract and the total antioxidant status in aqueous humor. Clin Chem Lab Med 2001, 39(2): 143-145.

157. Brooks SP, Ebenezer ND, Poopalasundaram S, Lehmann OJ, Moore AT, Hardcastle AJ: Identification of the gene for Nance-Horan syndrome (NHS). J Med Genet 2004, 41(10):768-771.

158. Sharma S, Burdon KP, Dave A, Jamieson RV, Yaron Y, Billson F, Van Maldergem L, Lorenz B, Gécz J, Craig JE: Novel causative mutations in patients with Nance-Horan syndrome and altered localization of the mutant NHS-A protein isoform. Mol Vis 2008, 14:1856-1864.

159. Naumann GO, Schlotzer-Schrehardt U, Kuchle M: Pseudoexfoliation syndrome for the comprehensive ophthalmologist Intraocular and systemic manifestations. Ophthalmology 1998, 105(6):951-968.

160. Wilson ME Jr, Trivedi RH, Biber JM, Golub R: Anterior capsule rupture and subsequent cataract formation in Alport syndrome. J AAPOS 2006, 10 (2):182-183.

161. Coulter JB 3rd, Phinizy JL, Hunnicutt RE, Baumgart MA, Hise EM, Marr LK: Effects of age, sex, cataract, and cataract surgery on serum gammacrystallin concentration. Ophthalmic Res 1999, 31(5):337-345.

162. Van Der Woerdt A: Lens-induced uveitis. Vet Ophthalmol 2000, 3(4): 227-234.

163. Saika S, Yamanaka O, Okada Y, Tanaka S, Miyamoto T, Sumioka T, Kitano A, Shirai K, Ikeda K: TGF beta in fibroproliferative diseases in the eye. Front Biosci (Schol Ed) 2009, 1:376-390.

164. Wormstone IM, Wang L, Liu CS: Posterior capsule opacification. Exp Eye Res 2009, 88(2):257-269.

165. Barraquer Rl, Michael R, Abreu R, Lamarca J, Tresserra F: Human lens capsule thickness as a function of age and location along the sagittal lens perimeter. Invest Ophthalmol Vis Sci 2006, 47(5):2053-2060.

166. Fisher RF, Pettet BE: The postnatal growth of the capsule of the human crystalline lens. J Anat 1972, 112(Pt 2):207-214.

167. Krag S, Olsen T, Andreassen T: Biomechanical characteristics of the human anterior lens capsule in relation to age. Invest Ophthalmol Vis Sci 1997, 38(2):357-363.

168. Sweeney MH, Truscott RJ: An impediment to glutathione diffusion in older normal human lenses: a possible precondition for nuclear cataract. Exp Eye Res 1998, 67(5):587-595.

169. Moffat BA, Landman KA, Truscott RJ, Sweeney MH, Pope JM: Age-related changes in the kinetics of water transport in normal human lenses. Exp Eye Res 1999, 69(6):663-669.

170. Bova LM, Sweeney MH, Jamie JF, Truscott RJ: Major changes in human ocular UV protection with age. Invest Ophthalmol Vis Sci 2001, 42(1): 200-205.

171. Truscott RJ: Age-related nuclear cataract-oxidation is the key. Exp Eye Res 2005, 80(5):709-725.

172. Spector A: Review: oxidative stress and disease. J Ocul Pharmacol Ther 2000, 16(2):193-201.

173. Barber GW: Human cataractogenesis: a review. Exp Eye Res 1973, 16(2):85-94.

174. Spector A: Oxidation and cataract. CIBA Found Symp 1984, 106:48-64.

175. Wistow G, Bernstein SL, Wyatt MK, Behal A, Touchman JW, Bouffard G, Smith $D$, Peterson $K$ : Expressed sequence tag analysis of adult human lens for the NEIBank Project: over 2000 non-redundant transcripts, novel genes and splice variants. Mol Vis 2002, 8:171-184.

176. Wride MA, Mansergh FC, Adams S, Everitt R, Minnema SE, Rancourt DE, Evans MJ: Expression profiling and gene discovery in the mouse lens. Mol Vis 2003, 9:360-396.

177. Mansergh FC, Wride MA, Walker VE, Adams S, Hunter SM, Evans MJ: Gene expression changes during cataract progression in Sparc null mice: differential regulation of mouse globins in the lens. Mol Vis 2004, 10:490-511.

178. Hawse JR, Hejtmancik JF, Huang Q, Sheets NL, Hosack DA, Lempicki RA, Horwitz J, Kantorow M: Identification and functional clustering of global gene expression differences between human age-related cataract and clear lenses. Mol Vis 2003, 9:515-537.

179. Medvedovic M, Tomlinson CR, Call MK, Grogg M, Tsonis PA: Gene expression and discovery during lens regeneration in mouse: regulation of epithelial to mesenchymal transition and lens differentiation. Mol Vis 2006, 12:422-440.

180. Bloemendal H, de Jong W, Jaenicke R, Lubsen NH, Slingsby C, Tardieu A: Ageing and vision: structure, stability and function of lens crystallins. Prog Biophys Mol Biol 2004, 86(3):407-485.

181. Pras E, Frydman M, Levy-Nissenbaum E, Bakhan T, Raz J, Assia El, Goldman B, Pras E: A nonsense mutation (W9X) in CRYAA causes autosomal recessive cataract in an inbred Jewish Persian family. Invest Ophthalmol Vis Sci 2000, 41(11):3511-3515.

182. Andley UP: Effects of alpha-crystallin on lens cell function and cataract pathology. Curr Mol Med 2009, 9(7):887-892.

183. Andley UP: AlphaA-crystallin R49Cneo mutation influences the architecture of lens fiber cell membranes and causes posterior and nuclear cataracts in mice. BMC Ophthalmol 2009, 9:4.

184. Bhagyalaxmi SG, Srinivas P, Barton KA, Kumar KR, Vidyavathi M, Petrash JM, Bhanuprakash Reddy G, Padma T: A novel mutation (F71L) in alphaAcrystallin with defective chaperone-like function associated with agerelated cataract. Biochim Biophys Acta 2009, 1792(10):974-981.

185. Huang Q, Ding L, Phan KB, Cheng C, Xia CH, Gong X, Horwitz J: Mechanism of cataract formation in alphaA-crystallin Y118D mutation. Invest Ophthalmol Vis Sci 2009, 50(6):2919-2926.

186. Li FF, Yang M, Ma X, Zhang Q, Zhang M, Wang SZ, Zhu SQ: Autosomal dominant congenital nuclear cataracts caused by a CRYAA gene mutation. Curr Eye Res 2010, 35(6):492-498.

187. Pang M, Su JT, Feng S, Tang ZW, Gu F, Zhang M, Ma X, Yan YB: Effects of congenital cataract mutation $\mathrm{R} 116 \mathrm{H}$ on alphaA-crystallin structure, function and stability. Biochim Biophys Acta 2010, 1804(4):948-956.

188. Raju M, Santhoshkumar P, Sharma KK: Cataract-causing alphaAG98Rcrystallin mutant dissociates into monomers having chaperone activity. Mol Vis 2011, 17:7-15.

189. Stella DR, Floyd KA, Grey AC, Renfrow MB, Schey KL, Barnes S: Tissue localization and solubilities of alphaA-crystallin and its numerous C-terminal truncation products in pre- and postcataractous ICR/f rat lenses. Invest Ophthalmol Vis Sci 2010, 51(10):5153-5161.

190. Vicart P, Caron A, Guicheney P, Li Z, Prevost MC, Faure A, Chateau D, Chapon F, Tomé F, Dupret JM, Paulin D, Fardeau M: A missense mutation in the alphaB-crystallin chaperone gene causes a desmin-related myopathy. Nat Genet 1998, 20(1):92-95.

191. Brady JP, Garland DL, Green DE, Tamm ER, Giblin FJ, Wawrousek EF: AlphaB-crystallin in lens development and muscle integrity: a gene knockout approach. Invest Ophthalmol Vis Sci 2001, 42(12):2924-2934.

192. Chen Q, Ma J, Yan M, Mothobi ME, Liu Y, Zheng F: A novel mutation in CRYAB associated with autosomal dominant congenital nuclear cataract in a Chinese family. Mol Vis 2009, 15:1359-1365.

193. Chen Q, Yan M, Xiang F, Zhou X, Liu Y, Zheng F: Characterization of a mutant $\mathrm{R} 11 \mathrm{H}$ alphaB-crystallin associated with human inherited cataract. Biol Chem 2010, 391(12):1391-1400.

194. Liu M, Ke T, Wang Z, Yang Q, Chang W, Jiang F, Tang Z, Li H, Ren X, Wang X, Wang T, Li Q, Yang J, Liu J, Wang QK: Identification of a CRYAB mutation associated with autosomal dominant posterior polar cataract in a Chinese family. Invest Ophthalmol Vis Sci 2006, 47(8):3461-3466.

195. Liu Y, Zhang X, Luo L, Wu M, Zeng R, Cheng G, Hu B, Liu B, Liang JJ, Shang F: A novel alphaB-crystallin mutation associated with autosomal dominant congenital lamellar cataract. Invest Ophthalmol Vis Sci 2006, 47(3):1069-1075.

196. Srivastava OP, Srivastava K: Existence of deamidated alphaB-crystallin fragments in normal and cataractous human lenses. Mol Vis 2003, 9 : 110-118.

197. Bateman JB, von-Bischhoffshaunsen FR, Richter L, Flodman P, Burch D, Spence MA: Gene conversion mutation in crystallin, beta-B2 (CRYBB2) in a Chilean family with autosomal dominant cataract. Ophthalmology 2007, 114(3):425-432.

198. Cohen D, Bar-Yosef U, Levy J, Gradstein L, Belfair N, Ofir R, Joshua S, Lifshitz T, Carmi R, Birk OS: Homozygous CRYBB1 deletion mutation underlies autosomal recessive congenital cataract. Invest Ophthalmol Vis Sci 2007, 48(5):2208-2213.

199. Gu Z, Ji B, Wan C, He G, Zhang J, Zhang M, Feng G, He L, Gao L: A splice site mutation in CRYBA1/A3 causing autosomal dominant posterior polar cataract in a Chinese pedigree. Mol Vis, 16:154-160.

200. Li FF, Zhu SQ, Wang SZ, Gao C, Huang SZ, Zhang M, Ma X: Nonsense mutation in the CRYBB2 gene causing autosomal dominant progressive polymorphic congenital coronary cataracts. Mol Vis 2008, 14:750-755. 
201. Lou D, Tong JP, Zhang LY, Chiang SW, Lam DS, Pang CP: A novel mutation in CRYBB2 responsible for inherited coronary cataract. Eye (Lond) 2009, 23(5):1213-1220.

202. Lu S, Zhao C, Jiao H, Kere J, Tang X, Zhao F, Zhang X, Zhao K, Larsson C: Two Chinese families with pulverulent congenital cataracts and deltaG91 CRYBA1 mutations. Mol Vis 2007, 13:1154-1160.

203. Meyer E, Rahman F, Owens J, Pasha S, Morgan NV, Trembath RC, Stone EM, Moore AT, Maher ER: Initiation codon mutation in betaB1-crystallin (CRYBB1) associated with autosomal recessive nuclear pulverulent cataract. Mol Vis 2009, 15:1014-1019.

204. Mothobi ME, Guo S, Liu Y, Chen Q, Yussuf AS, Zhu X, Fang Z: Mutation analysis of congenital cataract in a Basotho family identified a new missense allele in CRYBB2. Mol Vis 2009, 15:1470-1475.

205. Pauli S, Soker T, Klopp N, Illig T, Engel W, Graw J: Mutation analysis in a German family identified a new cataract-causing allele in the CRYBB2 gene. Mol Vis 2007, 13:962-967.

206. Santhiya ST, Kumar GS, Sudhakar P, Gupta N, Klopp N, Illig T, Söker T, Groth M, Platzer M, Gopinath PM, Graw J: Molecular analysis of cataract families in India: new mutations in the CRYBB2 and GJA3 genes and rare polymorphisms. Mol Vis 2010, 16:1837-1847.

207. Wang J, Ma X, Gu F, Liu NP, Hao XL, Wang KJ, Wang NL, Zhu SQ: A missense mutation S228P in the CRYBB1 gene causes autosomal dominant congenital cataract. Chin Med J (Engl) 2007, 120(9):820-824.

208. Wang KJ, Wang BB, Zhang F, Zhao Y, Ma X, Zhu SQ: Novel beta-crystallin gene mutations in Chinese families with nuclear cataracts. Arch Ophthalmol 2011, 129(3):337-343.

209. Wang L, Lin H, Gu J, Su H, Huang S, Qi Y: Autosomal-dominant cerulean cataract in a Chinese family associated with gene conversion mutation in beta-B2-crystallin. Ophthalmic Res 2009, 41(3):148-153.

210. Yang G, Zhai X, Zhao J: A recurrent mutation in CRYBA1 is associated with an autosomal dominant congenital nuclear cataract disease in a Chinese family. Mol Vis 2011, 17:1559-1563.

211. Yang J, Zhu Y, Gu F, He X, Cao Z, Li X, et al: A novel nonsense mutation in CRYBB1 associated with autosomal dominant congenital cataract. Mol Vis 2008, 14:727-731.

212. Yao K, Li J, Jin C, Wang W, Zhu Y, Shentu X, Wang Q: Characterization of a novel mutation in the CRYBB2 gene associated with autosomal dominant congenital posterior subcapsular cataract in a Chinese family. Mo/ Vis 2011 17:144-152.

213. Zhang J, Li J, Huang C, Xue L, Peng Y, Fu Q, Gao L, Zhang J, Li W: Targeted knockout of the mouse betaB2-crystallin gene (Crybb2) induces agerelated cataract. Invest Ophthalmol Vis Sci 2008, 49(12):5476-5483.

214. Zhou G, Zhou N, Hu S, Zhao L, Zhang C, Qi Y: A missense mutation in CRYBA4 associated with congenital cataract and microcornea. Mol Vis 2010, 16:1019-1024.

215. Zhu Y, Shentu X, Wang W, Li J, Jin C, Yao K: A Chinese family with progressive childhood cataracts and IVS3 + 1 G > A CRYBA3/A1 mutations. Mol Vis 2010, 16:2347-2353.

216. Banerjee PR, Pande A, Patrosz J, Thurston GM, Pande J: Cataract-associated mutant E107A of human gammaD-crystallin shows increased attraction to alpha-crystallin and enhanced light scattering. Proc Natl Acad Sci U S A 2011, 108(2):574-579.

217. Gong B, Zhang LY, Lam DS, Pang CP, Yam GH: Sodium 4-phenylbutyrate ameliorates the effects of cataract-causing mutant gammaD-crystallin in cultured cells. Mol Vis 2010, 16:997-1003.

218. Hansen L, Yao W, Eiberg H, Kjaer KW, Baggesen K, Hejtmancik JF, Rosenberg $\mathrm{T}$ : Genetic heterogeneity in microcornea-cataract: five novel mutations in CRYAA, CRYGD, and GJA8. Invest Ophthalmol Vis Sci 2007, 48(9):3937-3944.

219. Khan AO, Aldahmesh MA, Ghadhfan FE, Al-Mesfer S, Alkuraya FS: Founder heterozygous P23T CRYGD mutation associated with cerulean (and coralliform) cataract in 2 Saudi families. Mol Vis 2009, 15:1407-1411.

220. Li F, Wang S, Gao C, Liu S, Zhao B, Zhang M, Huang S, Zhu S, Ma X: Mutation G61C in the CRYGD gene causing autosomal dominant congenital coralliform cataracts. Mol Vis 2008, 14:378-386.

221. McManus JJ, Lomakin A, Ogun O, Pande A, Basan M, Pande J, Basan M, Pande J, Benedek GB: Altered phase diagram due to a single point mutation in human gammaD-crystallin. Proc Natl Acad Sci U S A 2007, 104(43):16856.

222. Messina-Baas OM, Gonzalez-Huerta LM, Cuevas-Covarrubias SA: Two affected siblings with nuclear cataract associated with a novel missense mutation in the CRYGD gene. Mol Vis 2006, 12:995-1000.
223. Moreau KL, King J: Hydrophobic core mutations associated with cataract development in mice destabilize human gammaD-crystallin. J Biol Chem 2009, 284(48):33285-33295.

224. Pande A, Ghosh KS, Banerjee PR, Pande J: Increase in surface hydrophobicity of the cataract-associated P23T mutant of human gammaD-crystallin is responsible for its dramatically lower, retrograde solubility. Biochemistry 2010, 49(29):6122-6129.

225. Pande A, Gillot D, Pande J: The cataract-associated R14C mutant of human gamma D-crystallin shows a variety of intermolecular disulfide cross-links: a Raman spectroscopic study. Biochemistry 2009, 48(22):4937-4945.

226. Pande A, Zhang J, Banerjee PR, Puttamadappa SS, Shekhtman A, Pande J: NMR study of the cataract-linked P23T mutant of human gammaDcrystallin shows minor changes in hydrophobic patches that reflect its retrograde solubility. Biochem Biophys Res Commun 2009, 382(1):196-199.

227. Papanikolopoulou K, Mills-Henry I, Thol SL, Wang Y, Gross AA, Kirschner DA Decatur SM, King J: Formation of amyloid fibrils in vitro by human gammaD-crystallin and its isolated domains. Mol Vis 2008, 14:81-89.

228. Roshan M, Vijaya PH, Lavanya GR, Shama PK, Santhiya ST, Graw J, Gopinath PM, Satyamoorthy K: A novel human CRYGD mutation in a juvenile autosomal dominant cataract. Mol Vis 2010, 16:887-896.

229. Sahin E, Jordan JL, Spatara ML, Naranjo A, Costanzo JA, Weiss WF, Robinson AS, Fernandez EJ, Roberts CJ: Computational design and biophysical characterization of aggregation-resistant point mutations for gammaD crystallin illustrate a balance of conformational stability and intrinsic aggregation propensity. Biochemistry 2011, 50(5):628-639.

230. Santana A, Waiswol M, Arcieri ES, de Vasconcellos JP C, Barbosa De Melo M: Mutation analysis of CRYAA, CRYGC, and CRYGD associated with autosomal dominant congenital cataract in Brazilian families. Mol Vis 2009, 15:793-800.

231. Vendra VP, Balasubramanian D: Structural and aggregation behavior of the human gammaD-crystallin mutant E107A, associated with congenital nuclear cataract. Mol Vis 2010, 16:2822-2828.

232. Wang K, Cheng C, Li L, Liu H, Huang Q, Xia CH, Yao K, Sun P, Horwitz J, Gong X: GammaD-crystallin associated protein aggregation and lens fiber cell denucleation. Invest Ophthalmol Vis Sci 2007, 48(8):3719-3728.

233. Zhang LY, Gong B, Tong JP, Fan DS, Chiang SW, Lou D, Lam DS, Yam GH, Pang CP: A novel gammaD-crystallin mutation causes mild changes in protein properties but leads to congenital coralliform cataract. Mol Vis 2009, 15:1521-1529.

234. Zhang LY, Yam GH, Fan DS, Tam PO, Lam DS, Pang CP: A novel deletion variant of gammaD-crystallin responsible for congenital nuclear cataract. Mol Vis 2007, 13:2096-2104.

235. Arrigo AP, Simon S: Expression and functions of heat shock proteins in the normal and pathological mammalian eye. Curr Mol Med 2010, 10(9):776-793.

236. Graw J: Genetics of crystallins: cataract and beyond. Exp Eye Res 2009, 88(2):173-189.

237. Jezek $P$, Hlavata $L$ : Mitochondria in homeostasis of reactive oxygen species in cell, tissues, and organism. Int J Biochem Cell Biol 2005, 37(12):2478-2503.

238. Qian W, Shichi H: Acetaminophen produces cataract in DBA2 mice by Ah receptor-independent induction of CYP1A2. J Ocul Pharmacol Ther 2000, 16(4):337-344.

239. Nair KS, Patel KV, Gandhi TR: Is cytochrome modulation the new frontier for decreasing the risk of cataract? Indian J Pharmacol 2009, 41(2):72-74.

240. Suetsugu-Maki R, Maki N, Fox TP, Nakamura K, Cowper Solari R, Tomlinson CR, Qu H, Lambris JD, Tsonis PA: A complement receptor C5a antagonist regulates epithelial to mesenchymal transition and crystallin expression after lens cataract surgery in mice. Mol Vis 2011, 17:949-964.

241. Truscott RJ: Presbyopia. Emerging from a blur towards an understanding of the molecular basis for this most common eye condition. Exp Eye Res 2009, 88(2):241-247.

242. Ziebarth NM, Borja D, Arrieta E, Aly M, Manns F, Dortonne I, Nankivil D, Jain R, Parel JM: Role of the lens capsule on the mechanical accommodative response in a lens stretcher. Invest Ophthalmo/ Vis Sci 2008, 49(10):4490-4496.

243. Brekken RA, Sage EH: SPARC, a matricellular protein: at the crossroads of cell-matrix communication. Matrix Biol 2001, 19(8):816-827.

244. Keller KE, Aga M, Bradley JM, Kelley MJ, Acott TS: Extracellular matrix turnover and outflow resistance. Exp Eye Res 2009, 88(4):676-682.

245. Carinato ME, Walter BE, Henry JJ: Xenopus laevis gelatinase B (Xmmp-9): development, regeneration, and wound healing. Dev Dyn 2000, 217(4):377-387. 
246. Fisher RF, Hayes BP: The elastic constants and ultrastructure organization of regenerated basement membrane (lens capsule). Q J Exp Physiol 1982, 67(2):213-224.

247. Hadassah J, Bhuvaneshwari N, Rao U, Sehgal PK: Evaluation of succinylated collagen bandage lenses in corneal healing by the expression of matrix metalloproteinases (MMP-2 and MMP-9) in tear fluid. Ophthalmic Res 2009, 42(2):64-72.

248. Hodgkinson LM, Wang L, Duncan G, Edwards DR, Wormstone IM: ADAM and ADAMTS gene expression in native and wound healing human lens epithelial cells. Mol Vis 2010, 16:2765-2776.

249. Kawashima Y, Saika S, Miyamoto T, Yamanaka O, Okada Y, Tanaka S, Ohnishi $Y$ : Matrix metalloproteinases and tissue inhibitors of metalloproteinases of fibrous humans lens capsules with intraocular lenses. Curr Eye Res 2000, 21(6):962-967.

250. Malloch EL, Perry KJ, Fukui L, Johnson VR, Wever J, Beck CW, King MW, Henry JJ: Gene expression profiles of lens regeneration and development in Xenopus laevis. Dev Dyn 2009, 238(9):2340-2356.

251. Henry JJ, Tsonis PA: Molecular and cellular aspects of amphibian lens regeneration. Prog Retin Eye Res 2010, 29(6):543-555.

252. Alapure BV, Praveen MR, Gajjar D, Vasavada AR, Rajkumar S, Johar K: Matrix metalloproteinase- 9 activity in human lens epithelial cells of cortical, posterior subcapsular, and nuclear cataracts. J Cataract Refract Surg 2008 34(12):2063-2067.

253. Nathu Z, Dwivedi DJ, Reddan JR, Sheardown H, Margetts PJ, West-Mays JA: Temporal changes in MMP mRNA expression in the lens epithelium during anterior subcapsular cataract formation. Exp Eye Res 2009, 88 (2):323-330.

254. West-Mays JA, Pino G: Matrix metalloproteinases as mediators of primary and secondary cataracts. Expert Rev Ophthalmol 2007, 2(6):931-938.

255. Bhavsar RB, Makley LN, Tsonis PA: The other lives of ribosomal proteins. Hum Genomics 2010, 4(5):327-344.

256. Kondrashov N, Pusic A, Stumpf CR, Shimizu K, Hsieh AC, Xue S, Ishijima J, Shiroishi T, Barna M: Ribosome-mediated specificity in Hox mRNA translation and vertebrate tissue patterning. Cell 2010, 145(3):383-397.

257. Topisirovic I, Sonenberg N: Translational control by the eukaryotic ribosome. Cell 2010, 145(3):333-334.

258. Curran SP, Ruvkun G: Lifespan regulation by evolutionarily conserved genes essential for viability. PLoS Genet 2007, 3(4):e56.

doi:10.1186/1479-7364-6-14

Cite this article as: Sousounis and Tsonis: Patterns of gene expression in microarrays and expressed sequence tags from normal and cataractous lenses. Human Genomics 2012 6:14.

\section{Submit your next manuscript to BioMed Central and take full advantage of:}

- Convenient online submission

- Thorough peer review

- No space constraints or color figure charges

- Immediate publication on acceptance

- Inclusion in PubMed, CAS, Scopus and Google Scholar

- Research which is freely available for redistribution 